\title{
REVEALING THE TRUTH: CATALONIA, THE SELF-SACRIFICIAL VICTIM OF SPAIN
}

\author{
Fernando León-Solís \\ (University of the West of Scotland) \\ Fernando.Leon-solis@uws.ac.uk
}

\begin{abstract}
Resumen: Este artículo ofrece un estudio de las estrategias narrativas empleadas por Josep Antoni Duran i Lleida, líder de la coalición catalanista de centro derecha, Convergència i Unió, en su discurso en defensa del nuevo Estatuto de Autonomía de Cataluña, presentado en las Cortes en 2005. El artículo sugiere que el discurso de Duran fue construido siguiendo los parámetros de una gran narrativa con sólidas bases historicas organizada alrededor de tres características interrelacionadas: a) una noción absoluta de 'verdad' y 'realidad' que la clase política catalana (que no la española) posee; b) un doble papel desempeñado por Cataluña como víctima y redentora de España; y c) la construcción del debate del Estatuto como un punto de inflexión en la historia de España, como el momento de posible redención de España con la ayuda de Cataluña. En el artículo se sugiere la idea de que este marco narrativo, que en última instancia evita la idea de separación total, es un reflejo de la posición dual de Cataluña como región con un fuerte sentido de la identidad, pero, a la vez, con sólidos intereses en el conjunto de España.
\end{abstract}

Palabras clave: Estatuto, Cataluña, verdad, narrativa, victimismo, redención.

Abstract: This article offers a analysis on the narrative strategies used by Josep Antoni Duran i Lleida, the leader of the center-right catalanist coalition Convergència $i$ Unió, in his speech in defence of the new Statute of Autonomy of Catalonia presented in the Spanish Parliament in 2005. The article suggests that Duran's speech followed a long-standing grand narrative frame organized around the following three interrelated features: a) an absolute notion of historico-political 'truth' and 'reality' that the Catalan (as opposed to Spanish) political classes are in possession of; b) the double role of Catalonia as victim and redeemer of Spain; and c) the construction of the Statute debate as a turning point in the history of Spain, as the moment for the potential redemption of Spain with the help of Catalonia. The article argues that this particular narrative framework, which ultimately precludes the idea of total separation, is a manifestation of the dual position of Catalonia within Spain as a region with a strong sense of identity but also with strong economic and political interests within Spain.

Keywords: Estatuto, Catalonia, truth, narrative, victimism, redemption.

\section{INTRODUCTION: THE NEW CATALAN STATUTE}

-wenty-five years after the promulgation of the 1979 Catalan Statute of Autonomy the process of reform of the statutes of all 17 Spanish Autonomous Communities was opened. To a certain extent, this happened as a consequence of political circumstances. In 2000 José Luís Rodríguez Zapatero became the general secretary of the PSOE with the help of the Catalan branch of the 
party, the Partit dels Socialistes de Catalunya (PSC), one of whose priorities was the reform of the Catalan Statute. The subsequent victory of the PSOE in the March 2004 general elections fell short of an overall majority and the socialists could only form a government with the parliamentary support of the pro-independence Catalan party Esquerra Republicana de Catalunya (ERC) and the leftist coalition Izquierda Unida (IU). The same three parties, led by the PSC, formed the Catalan Government (or Generalitat de Catalunya), in a coalition popularly known as the tripartito. The main opposition party in Catalonia then was the nationalist coalition Convérgencia $i$ Unió. The Proposal for the new Statute, approved by the Catalan Parliament in September 2005 with the votes of all parties except those of the all-Spanish center-right Partido Popular (PP), granted new powers to the Government of Catalonia (some exclusive, some concurrent and others shared with the State administration) in matters of culture, education, health, justice, environment, communications, transportation, commerce, public safety and local government. Most of the justice system would remain administered by all-Spanish judicial institutions, except for the so-called civil law. Even though the Spanish Prime Minister Rodríguez Zapatero personally announced he would accept the Statute as approved by the Catalan Parliament, a communiqué issued by the PSOE regarded some of the articles of the new Statute as 'of dubious constitutionality' (El Mundo, 4 October 2005), particularly those dealing with exclusive matters. The PP objected to the proposal on the grounds that it meant a potential sundering of the country on several fronts: on an economic front, it was argued that the Statute breached the economic and fiscal 'solidarity between regions', thus putting the unity of the Spanish market in jeopardy. On the political front, the main objection was to the definition of Catalonia as a 'nation', regarded as incompatible with the Spanish Constitution, which explicitly guarantees the indissoluble 'unity of the Spanish Nation'. The PP also claimed that the 1979 Statute was not being reformed by popular demand but as a result of regional politicians' desire to gain more power.

After approval in the Catalan Parliament, as established by Parliamentary regulations, the proposal was presented to the Central Parliament in the form of a bill. This was therefore a very preliminary stage in which Duran and other representatives of the Catalan governemnt asked for authorization to start a debate on the possibility to pass it as law. Duran's speech took place on 2 November 2005. At this point, it is important to point out that while Duran represented his own coalition he also claimed to be speaking on behalf of the whole of Catalonia, as he regarded $\mathrm{CiU}$ as the historical, 'central and principal expression of political Catalanism' (Duran, 2005: 3). He made this grand claim because his coalition had received the highest number of votes in the Catalan regional elections in 2003 although (as a consequence of a series of political pacts) they were in the opposition in the Catalan Parliament. 


\section{THE SPEECH ${ }^{1}$ AND ITS PARTS}

Duran's speech was divided into six parts entitled as follows: 'Introduction'; 'Political Climate of the Debate', 'Reform Proposal: Normalcy and Constitutionality of the Procedure', 'The Reasons Behind the Reform', 'Pedagogy: the Best Answer to Lack of Information and Falsehood'; and 'Final words'. The main arguments put forward in the speech were: a) Catalonia and Convergència i Unió in particular have always been at the service of Spain through pacts with right and left wing parties in the Spanish parliament; b) Catalonia's differentiated identity was the fundamental reason behind the new structure of the quasi-federal Spanish State or Estado de las Autonomías; c) the new Statute as approved by the Catalan Parliament did not trespass the limits set by the 1978 Constitution and did not change economic and fiscal solidarity between the regions or the unity of the Spanish market; f) the new Statute was needed because of the new international, cultural, economic and political reality brought about by the European Union and by globalisation, which urged a muscular sense of identity to face the human dimension of international mass immigration; g) it was also needed because of the refusal until then of all central governments to make public the fiscal balances (that is, regional fiscal contribution to and gains from the State), the refusal of Central governments to fully develop the 1979 Statute and the adoption of policies leading to a 'homogenizing development' of the Autnonomous Communities (Duran, 2005: 12); d) the PP and the PSOE have maintained a mendacious attitude towards Catalonia and the 1979 Statute as weel as the new Statute approved in the Catalan Parliament; and h) the debate on the Statute constituted a turning point, the moment in which to unveil the lies and to accept 'the truth' about Catalonia, if the whole of Spain were to avert political calamity.

\section{TRUTH AND NARRATIVE}

Only four paragraphs in the section entitled 'The Reasons behind the Reform' were devoted to an affirmative defense of the new Statute. In this minimum space Duran argued that the new world political and economic conditions and transformations undergone by Spain, namely the accession to the European Community and globalisation, had rendered the existing Statute obsolete (Duran, 2005: 11).

The minimum space devoted to this affirmative defence was overpowered by what can be regarded as a counteroffensive defence. And the way in which this counterattack was carried out constitutes the main focus of this article. As will be shown, Duran shored up the new Statute proposal by offering a series of narratives which problematized and deconstructed the allegedly negative conceptions of the relationship between Catalonia and the rest of Spain which, according to

1The speech analysed here was downloaded from the official website of CiU on 2 November 2005. All translations from this speech are my own. 
Duran, were held by the PP, the PSOE and the Spanish society in general. This article will also show that Duran based the legitimacy of his claims on an absolute concept of truth and reality. He argued that failure to understand or mere manipulations of the truth were the reasons behind the rejections of and objections to the new Statute.

The notion that Duran's speech was organized in narrative form does not constitute a novelty. In his Introduction to the Structural Analysis of Narratives, Barthes observes that: 'the narratives of the world are numberless' and omnipresent (Barthes, 1987: 79); 'narrative', Barthes argues, 'is present in every age, in every place, in every society (Barthes, 1987: 79). The universality of narratives has been made evident by many other authors. The French semiotician Greimas highlighted the heuristic value of narrative theory when applied not only to literary and mythical tales, but also to ethnological, psychological, sociological and scientific discourses. From the field of media analysis, John Fiske has observed that narrative is pervasive in all types of media products (Fiske, 1987: 128-129); and the French philosopher Jean-François Lyotard has studied the way modern science 'legitimates the rules of its own game' by means of narratives, by 'making an explicit appeal to some grand narrative' (Lyotard, 1984: xxiii).

In order to understand and explain the narrative frames used by Duran i Lleida in his defence of the Statute I propose to borrow Greimas's actantial framework, which, as Toolan describes it, constitutes a 'simple model of character roles in narrative which ... remains a tellingly workable anatomy' (1988: 93). Greimas went a step beyond Propp's model, which suggested that a fairy-tale can be reduced to thirty-one abstract functions understood 'as an act of a character, defined from the point of view of its significance for the course of the action' (Propp, 1984: 21). These functions are distributed among seven spheres of action performable by varying characters giving way to an actantial framework constituted by: the villain, the donor, the helper, the sought-for person, the dispatcher, the hero and the false hero. In the Greimasian formulation, these basic characters are called 'actants' distributed in the following pairs: Giver/Receiver

Subject/Object

Helper/Oponent.

As will be shown in this article, this scheme is productive for the intepretation of two opposing narrative interpretations of the relationship between Catalonia and the rest of Spain provided by Duran. On the one hand, he denounced as a lie and an error of judgement the narrative interpretation in which Catalonia is assigned the actantial role of the Opponent of Spain. This actantial arrangement could be represented like this:

\begin{tabular}{|l|c|l|}
\hline SUBJECT & OBJECT (in quest of) & OPPONENT \\
\hline Spain & Unity, Integrity & Catalonia \\
\hline
\end{tabular}


Instead he offered the opposite view: it is actually Spain that has acted as an Opponent (and a villain) to Catalonia:

\begin{tabular}{|l|l|l|}
\hline SUBJECT & \multicolumn{1}{|c|}{ OBJECT (in quest of) } & OPPONENT \\
\hline Catalonia & $\begin{array}{l}\text { Identity, Autonomy, Historical } \\
\text { Rights }\end{array}$ & Spain \\
\hline
\end{tabular}

These two opposite narrative frames are analysed in detail in section 4, entitled 'Catalonia is not the Enemy of Spain but its Victim'.

Duran's narrative counter-offensive was further complemented with the following one: Spain has been and still is generously helped by Catalonia. In this narrative Spain is the Receiver and Catalonia is the Giver (the donor in the Proppian formulation):

\begin{tabular}{|c|l|l|}
\hline SUBJECT/RECEIVER & OBJECT (in quest of) & GIVER \\
\hline Spain & $\begin{array}{l}\text { Modernity, development, } \\
\text { progress }\end{array}$ & Catalonia \\
\hline
\end{tabular}

When this role as beneficiary is juxtaposed to the role of victim Catalonia is allocated the double function of victim that sacrifices itself for the whole of Spain. The details of this narrative framework will be seen in section 5, entitled 'Spain is Victim and Benefactor of Spain'.

As will be argued in section 6, Duran spoke from a position of truth. Conversely, the all-Spanish political parties and the Spanish public opinion ${ }^{2}$ were characterized as lacking in truth. In his speech, Duran (not explicitly and not in these terms) explained that this deficiency had two different origins: error (an unconscious distance from the truth) and lie (a conscious distance from the truth). Section 7 will show how the debate of the new Statute was constructed as a Moment of Truth, as the potential point of no return in which Spain could be redeemed if the 'true' premises that Duran presented as 'undisputable' (Duran, 2005: 2) were accepted and disseminated. As will be seen, this moment of redemption was codified in terms of 'pedagogy'.

Section 8 will look into the historical links of this narrative, whereas the conclusion will (albeit briefly) look into the reasons of this particular reading of the relationship between Catalonia and the rest of Spain. 


\section{CATALONIA IS NOT THE ENEMY OF SPAIN BUT ITS VICTIM}

The definition of Catalonia as a nation was pivotal to Duran's attempt to disassemble and contest both Catalonia's characterization as 'anti-Spanish' and the depiction of the new Statute as a weapon that would jeopardize Spain's territorial and Constitutional integrity. On this point the PP's MPs were the target of his address:

with all due respect, you're wrong. You may think this is a strictly Catalan problem created by a few irresponsible, anti-Spanish radicals. You are wrong. Catalonia is not radical ... it is not anti-Spanish and it is not irresponsible... This is not a proposal aimed at separating from the rest of Spain; it is not the first step towards independence (Duran, 2005: 14).

The importance given to the exposure of this mistake ('you are wrong', Duran told MPs) was evidenced by its relevance within the speech - a whole section, entitled 'Reform Proposal: Normalcy and Constitutionality of the Procedure' was devoted to prove that the proposal was constitutional. In legal terms, the defence of the constitutionality of the proposal meant that it was not contrary to the definition of Spain, its political essence; and it did not constitute, therefore, an attack upon its unity.

This interpretation in which Catalonia was depicted as the enemy of Spain was directly contested with the insertion into the narrative of the proposition that Catalonia is not the enemy of Spain but its victim. This other frame showed one clear difference with the previous one: if Duran had at one time only blamed the PP for the 'wrong' characterization of Catalonia as enemy of Spain, now he extended his accusations to the whole of the Spanish political spectrum. As noted, Duran based the legitimacy of this counter-narrative on the concept of 'truth' and historical and economic 'facts'. As will be seen below, these historical facts were selected ${ }^{3}$ with the intention of proving three main interrelated points: a) the 'anti-Catalan' stance taken by the two main all-Spanish political parties; b) their changeable (and therefore untrustworthy) nature; and c) the merciless attitude of the Spanish State towards Catalonia.

The main historical references picked by Duran to demonstrate the act of victimisation of Catalonia on the part of the Spanish political system were the political pacts between the CiU and the PSOE and the PP. At this point some background might be useful. After the June 1993 general elections, the PSOE, faced with the inability to gain an overall majority, called for the participation of the $\mathrm{CiU}$ in central government. In the political negotiations that ensued, questions of devolved power to the regions and of the structure and unity of Spain came to the fore. The Socialists were heavily criticized by the PP for allegedly giving way to Catalanist pressure and for exposing the unity and survival of Spain as a nation. The criticisim of this pact was regarded by Duran in his 2005 speech as anti-Catalan, as 'the political attacks ... launched by the PP and their social and media support' (2005: 4).

'By using the verb 'select' I want to emphasize the idea that Duran's intepretation was an ideological construction. 
The second piece of historical 'evidence' chosen by Duran to prove the supposed rampant anti-Catalan stance of the Spanish political system was the election of 3 March 1996, which repeated the previous situation but in reverse. This time it was the PP that found itself forced to start negotiations with $\mathrm{CiU}$ in order to obtain their support, despite the political attacks they had launched against the Catalan coalition during the previous term. Some of the leaders of the PSOE maintained a critical attitude in the face of a possibility of an exchange of votes for an increase in the share of Catalonia in the National Budget. The PP was accused of appeasement and the whole process of the pact as being led by a mercantilist attitude. Apropos that pact, Duran told MPs in his 2005 speech that 'despite everything, despite our support to the PP for everyone's good, we were on the receiving end of the PSOE's savage lashing'. Attention should be paid here to the lexical choice 'savage', with which Duran constructs a political party wildly violent against Catalonia.

The suggestion that, despite the apparent differences, the PP and the PSOE maintain the same stance towards Catalonia (that is, they are virtually the same thing) was further supported by Duran's interpretation of the performance of these two parties when holding power in Central Government.

The basis of this negative portrayal was made to rest upon both the political attitude towards Catalan autonomy and their financial policies that, according to Duran, have been held by the PP and the PSOE. According to Duran the PSOE had promoted a 'homogenizing and unifying development of the Autonomous Communities' (2005:12), that is, they have maintained policies that run against the differentiated political identity of Catalonia. The important thing for this analysis is the violent characterization of the Socialist party: as far as attitudes to Catalan autonomy were concerned, Duran criticised 'an unjust use of the concept of basic statewide legislation, applied mercilessly by the PSOE from 82 to 93' (2005: 12).

But Catalonia was presented not just as the victim of a violent political system but also unfair and deceitful: Duran condemned Zapatero's government for not keeping his word of 'accepting the Statute approved by the Catalan government' (2005: 8). On the financial front Duran not only denounced the economic imbalance between Catalonia and Spain (what Catalonia contributes to and receives from the State) or, as he put it, 'the chronic fiscal deficit of Catalonia' (2005: 11)4, but also the deceptive and illegal 'refusal of the current government, as the PP did before, to make the fiscal balances public, despite being approved by the Lower and the Upper chambers' (2005: 11). Central governments (of any colour) were thus depicted not only as deceptive (refusing economic transparency) but also virtually unlawful (refusing to apply the laws approved by parliament).

${ }^{4}$ The fiscal balances were finally published in 2008 and revealed that, in this order, Madrid, Balearic Islands, Catalonia and Valencia contributed to the State more than they gained back. 
In a further twist in his valorization of the Spanish State, Duran accused its 'governments and/or legislators' of being the ultimate cause of the reform of the Statute that he was defending. If the governments of the State had not failed to apply the law, 'if nothing of that had happened' Duran argued, 'we would not be here today putting forward a reform of the Statute' (2005: 12). This idea was further reiterated when he stated that 'one could say that the 1979 Statute is the necessary tool' to face the challenges of the new globalized world (2005: 12).

This characterization of the Statute as a 'reaction weapon' could be regarded as contradictory with the portrayal of Catalonia as a victim of Spain. But, as a matter of fact, it rather strengthened it as it depicted Catalonia as the sufferer that reacts against injustice when the unfair treatment has reached its limit. It also implied that Catalan nationalist demands are not a mere whim but a fair reaction to the violent and deceitful attitude of the Spanish political system.

Finally, the alleged heavy-handedness of the central governments justified, according to Duran, one of the most discussed features of the proposed reform of the Statute: the thorough and drawn out definition of some of its legal concepts which many regarded as excessively regulating and controling. For Duran, as representative of a liberal coalition, the meticulousness of the text personally felt 'lengthy, and detailed' but it was justified by the allegedly long-standing ruthless attitude of the Spanish state. '[T]he Catalan legislators', as he put it, 'have their reasons that justified the technique used' (2005: 20). These 'reasons' were, according to Duran, the past sufferings of Catalonia at the hands of central Governments:

The experience in the process of devolution of power forces the Catalan legislators of apply the bandage before the wound appears, because they know that the current Statute is full of scars caused by the scissor cuts inflicted by the different governments and legislators (Duran, 2005: 21).

Here the role of Catalonia as victim was construed from two temporal perspectives. From the point of view of the past, the 1979 Statute (the political identity of Catalonia) was presented as a creature scarred and wounded by the State - Duran could have hardly used a most expressive metaphor to convey the image of the innocent victim. From the point of view of the future, the policy of applying 'the bandage before the wound appears' implied the certainty of forthcoming attacks on the part of central Governments, the conviction that Catalonia would continue being victimized.

\section{CATALONIA IS THE VICTIM AND BENEFACTOR OF SPAIN}

In parallel to the narrative line in which Catalonia was portrayed as the victim of Spain, Duran put forward another narrative interpretation in which Catalonia was represented as the benefactor of Spain, its donor. Reiterating the idea that Catalonia is not the villain of Spain, Duran further affirmed that 'Catalonia's specificity', that is, its differentiated political and cultural identity, 'has never weakened nor weighed down Spain' (Duran, 2003: 3). And straight away he clarified: 
Quite the opposite, the expression of that difference, in the form of political Catalanism, has always been at the service of regenerationism in Spain, of its modernization, in short, of the democratic, economic and social progress of the whole of the peoples of Spain (2005: 3).

'Regenerationism', which appeared with small type in the text should be interpreted in two ways: not only in reference to a general positive attitude towards the renewal of the country, but also as the end of $19^{\text {th }}$ century ideological movement whose aspiration was the modernization of Spain through 'science and positivism' (Fox, 1997: 56) and through its 'Europeanization'. In either sense of the word, Duran assigned Catalonia an active role in the 'modernization' and 'progress' undergone by Spain.

The historical references chosen by Duran to prove this point concentrated mainly in the post-Franco period. The first one alluded to what has been regarded as the re-foundational moment of the State of the new Spain: the writing of its 1978 Constitution (González 1997: 9). As illustrated in the following exerpt (rather lengthy but essential for the analysis) Duran emphasized the idea that Catalonia is not a destructive force within the State, but rather a constructive one; more precisely, the ultimate cause behind the administrative structure of the new Spain:

you could state what is known to be untrue in the hope that, by insisting, it could become true... [but] ... the truth is none other than the fact that Catalonia ... is basically the reason behind article VII of the Constitution. Without the Catalan national sentiment the Spanish Constitution would not have even mentioned the Autonomous Communities and while they are an outcome of the Constitution ... Catalonia, on the other hand, is the cause behind that constitutional article. We are the reason why Autonomous Communities exist, even though very few of us demanded them. But it has been good for Spain and we celebrate it. Catalonia's claims were not, despite the controversy it generated, negative for the peoples of Spain, but rather the opposite (Duran, 2005: 2).

Apart from the role fulfilled by Catalonia in this inaugural moment of the new Spain seen in this passage, Duran further assigned the political coalition he represented (and which, as noted before, he saw as the representative of Catalonia) a vital function in key moments of the recent history of Spain. He argued that $\mathrm{CiU}$ involvement and parliamentary proposals 'have unambiguously had' the aim of turning Spain into a 'great country' (Duran, 2005: 3). He illustrated this point by mentioning CiU's participation in

the writing-up and defense of the Constitution, the Moncloa Pacts ${ }^{5}$, in the period after the 23 February coup d'etat, in the investiture of Calvo Sotelo ${ }^{6}$, in the fight against terrorism,

\footnotetext{
${ }^{5}$ The Moncloa Pacts were a series of economic agreements that helped Spain move smoothly throughout the transitional period to democracy after the death of Franco. The salient feature of these pacts is that they were based on general consensus.

${ }^{6}$ Calvo Sotelo became Prime Minister after the failed 23 Feburary 1981 coup d'etat. All parties gave their support to him as an indication of their strong and united defense of the fledgling Spanish democracy.
} 
in foreign and defense policy, in the inspiration, impulse and approval of economic, fiscal and social measures that have helped make of Spain a great county of great opportunities and future possibilities (Duran, 2005: 3).

As far as the policies implemented to make it possible for Spain to finally join the European Monetary Union in 2001, Duran confidently remarked that 'what is undisputable is that who made it possible' from 1993 to 2000 was Convergència i Unió ${ }^{7}$ (Duran, 2005: 3).

This key role granted by Duran to Catalonia in the history of Spain can be further understood by looking into the insights of Frederic Jameson in The PrisonHouse of Language. Jameson ventures that 'the center of gravity of the narrated events lies not in the fact of the change, but in the explanation of the change, in the middle term which modulates from one state to the other' (Jameson, 1974: 67). This perspective (which applies well to Duran's portrayal of Spain's transformation in recent years) places the highest importance on the figure of the donor, who becomes, then 'the element which explains the changes described in the story ... and which is therefore somehow responsible for the 'storiness' of the story in the first place' (Jameson, 1974: 67). As noted above, Catalonia was portrayed as the ultimate reason behind the essence of the new Spanish state; it was represented as the cause behind its 'storiness', since it was Catalonia that, according to Duran, sowed the seeds for its conception. Duran also maintained that Catalonia is the vital cause behind the positive changes Spain has undergone in recent years. The importance of the existence of such a mediator is spelled out by Jameson in the following terms:

in the beginning the hero is never strong enough to conquer by himself. He suffers from some initial lack of being: either he is simply not strong enough or not courageous enough, or else he is too naive and simple-minded to know what to do with his strength. The donor is the complement, the reverse, of this basic ontological weakness (Jameson, 1974: 67-68).

According to Duran's account, on the inaugural moments of the new State after Franco's death, Spain's 'ontological weakness' consisted in its lack of vision on the worth and merit of a decentralized structure - a structure that, as quoted above, 'has been good for Spain' although, 'very few of us demanded' (Duran, 2005: 2). Spain's 'ontological weakness' was also overcome, according to Duran, thanks to Catalan intervention during key moments of the transition to demoracy and beyond.

A final implication of the choice of the role of donor is that Catalonia was construed as 'ex-centric' (Jameson, 1974: 68) to Spain, as a character that helped Spain transform and surmount its 'ontological weakness' but constitutes a different

\footnotetext{
${ }^{7}$ Duran was here, on the one, hand highlighting CiU's support for European Monetary Union and all the fiscal and economic measures it demanded; and, on the other, diminishing the impotance of the PP and PSOE, who actually led the implementation of those measures as the holders of power in Central Government.
} 
character acting from the periphery. That is the implication of Duran's words in the sense that 'only being what we are, in our liberty, can we be useful to Spain' (2005: 14); that is, Catalonia can only act as a donor of Spain as a differentiated entity.

In narrative terms, this double actantial role of Catalonia as victim and donor is not necessarily a contradiction but the result of being present in two 'spheres of action' (the one of the victim and the one of the donor) (Propp, 1984: 48). The important thing to note, however, is that in Duran's speech Catalonia is able to occupy these two spheres by means of a system of concession - i.e. Catalonia is the donor or the benefactor of Spain despite being its victim. This act of yielding was codified in terms of sacrifice. This was emphasized in the final words of the introduction of the speech in which Duran brought to the fore the idea that notwithstanding Spain's long-standing abuse, Catalonia has been and still is its only and true champion:

'The truth is that Catalonia and $\mathrm{CiU}$ have contributed in their utmost towards the general interest of Spain ... Being Catalan nationalists we have never felt the temptation to place party interests over those of the state, a temptation to which both sides of this chamber have succumbed' (Duran, 2005: 5).

This ultimate sacrifice was exemplified by Duran with a further reference to what Duran regarded as two landmarks in the recent history of Spain: the pacts with the PSOE and the PP in 1993 and 1996, respectively. Regarding the pact with the PSOE, according to Duran CiU provided 'political stability to the most difficult period of a Socialist government. Taking electoral risks ${ }^{8}$ and sacrificing the legitimate interests of the coalition. Resisting the political attacks' of the PP and their media support (Duran, 2005: 4). The second sacrificial moment was illustrated by Duran with a very specific incident that took place the night of PP's electoral victoy in 1996, in which a group of defiant PP voters shouted Pujol, enano, habla castellano ${ }^{9}$ (Pujol, you dwarf, speak Castillian). In his 2005 speech Duran stated that 'despite that, Pujol and CiU risked their electoral future because they are of a greater political stature than those who so often claim to be saving Spain' (2005: 4).

\section{TRUTH AND PEDAGOGY}

As noted in section 3, Duran based the claims of his speech on an absolute concept of truth. The importance granted in the speech to the concept truth and its revelation is apparent by its presiding position in the opening words of this speech, where Duran, against the notion that the new Statute would constituted

\footnotetext{
${ }^{8}$ According to Duran, his coalition was taking risks because they were supporting a party accused of corruption and centralism.

9Jordi Pujol is the former president of the Catalan Government, central figure of moderate Catalanism for twenty-five years and the leader of the CiU in 1996.
} 
a violation of the Spanish Constitution, announced: 'I think it is essential to stress some indisputable truths' (2005: 2). The soundness of the assertions in the rest of the speech derived from the fact that they were regarded as 'truths' but also, and very importantly, because they were deemed 'undisputable ${ }^{10}$ '. The presiding position allocated to the notion of truth was complemented and reinforced by the high frequency of appearance of this word, its synonyms and other interrelated ideas. In order to support his claims Duran mentioned 'Truth' ten times (once appearing as 'the simple truth' (2005: 18)); 'reality' (that is, true facts) was refered to in five occasions, whereas 'veracity' and 'common sense' were used once each.

The degree of acceptance and determination to make public the truth put forward by Duran were also the basis for Duran's valorization of the PP and the PSOE and the Spanish political system as a whole. This portrayal was carried out in two different ways. The first one, reserved for the PP, was done in terms of 'mistake': that is, the PP was erroneously accepting and promoting the lie that Catalonia is the enemy of Spain. As seen in section 4, in his attempt to disassemble accusations of anti-Constitutionalism held by the PP, Duran addressed the PP MPs with 'with all due respect, you are wrong. You might think that this is a strictly Catalan problem generated by a few radical, anti-Spanish and irresponsible people. You are wrong' (2005: 14). The PP was accused of being mistaken on four occasions.

Furthermore, the Spanish political class was also depicted as mendacious and deceptive, that is, as consciously disseminating a lie (that Catalonia acts against Spain) or hiding the truth (that Catalonia is in fact Spain's benefactor or donor). Duran accused the two main Spanish parties of demagoguery four times; he denounced their claims as false on five occasions; and twice pointed at them as driven by a desire to manipulate and confuse public opinion. For instance, Duran put the blame of the current political context of 'agitation and tension in this Chamber and in Spanish society' on the PP politicians for being demagogues, that is, for being ruled not by truth but by prejudice and passions: '[l]t is demagoguery', declared Duran, 'that makes certain leading politicians state that we are on the verge of the abyss', that is, of the sundering of Spain (2005: 6).

In the section entitled 'Political Climate of the Debate', Duran addressed directly Mariano Rajoy, the leader of the PP with the following accusation:

'Your party ranks, and even yourself, have tried to maliciously differentiate between a few politicians - by the way 120 out of $135 \mathrm{MPs}^{11}$ - and the people of Catalonia. This is not the Statute of a few politicians, but of the whole of Catalonia and it represents the whole of society. To say the opposite is a fraudulent attempt to confuse the Spanish public opinion and a refusal to uphold the democratic principle of respect to institutions and their representativenes.' (2005: 13).

\footnotetext{
${ }^{10}$ 'verdades inapelables' in the Spanish original.

${ }^{11}$ Here Duran was referring here to the Catalan Parliament and the number of MPs (120) who voted in favour of the new Statute.
} 
This indictment of maliciousness and fraud (which again categorized the PP as a character not ruled by the truth but by a will to do harm for vicious purposes) was further extended to the whole of the Spanish political system. It is in this pan-Spanish context that the following attack against the PP and the PSOE regarding the concepts of 'freedom of speech' and 'freedom of poltical action' must be understood: 'they are freedoms', Duran declared 'that become dignified when they are accompanied by responsibility and truthfulness. Two virtues, which, I am afraid, have been absent these days in which so many lies have been repeated.' (2005: 6 ). Along the same line, the depiction of the new Statute proposal as contrary to the Constitution was deemed an act of falsification or, in Duran's own expressive words, as 'despicable and badly-intentioned manipulation'12 (Duran, 2005: 19).

The denunciation of this lack of respect for the truth on the part of the PP and the PSOE was also launched when discussing the allegedly changing attitude of these two parties, which (according to Duran) regard Catalonia as an enemy or a helper of Spain depending on whether or not Catalan nationalists are needed to support governments in Madrid. In this respect he asked rhetorically:

How can they maintain, as it suits them best, that we represent good and evil; that we are people with a steady sense of State or irresponsible and vile separatists; that we are trustworthy, hard-working, innovative and an example to follow or a bunch of lice whose only intention is to choke the State and the Autnonomous Communities? (Duran, 2005: 4).

'[A]s it suits them best' construed the PP and the PSOE as two parties not ruled by the truth (or 'reality', in Duran's words) or by a fixed set of values but by particular interests of the moment. All in all, Duran's choice of words depicted the Spanish political system not only as untrustworthy for their disrespect for truth and reality but also for its inconsistency, and for its fickleness, in relation to Catalonia.

\section{THE MOMENT OF TRUTH}

Notwithstanding the negative characterization of the Spanish political system put forward by Duran throughout the whole of his speech, he left open the possibility of its redemption - a redemption in which the concept of truth would again take up a central position. Indeed, for Duran the debate was a Moment of Truth in the two senses of the expression: a) as a moment of revelation of the truth; and $b$ ) as a make-or-break point. Let us start by considering Duran's conception of the debate on the Statute as a moment of revelation of the truth. In the early stages of his speech, quoting the poet Juan Ramón Jiménez, Duran grandly proclaimed that '[i]t is time [...] to appeal to intelligence and to give things their right name' (2005: 8). Consistent with the characterization of Spanish political parties

\footnotetext{
${ }^{12}$ As noted, the extent to which the new Statute was constitutional or not was still being assessed by the Constitutional Tribunal at the moment of writing this article.
} 
as dishonest characters, the exposure and clarification of the truth was codified as a process of unveiling; hence the announcement that 'the time has come to Spain to unmask those who driven by mere party and electoral interests interpret reality as it suits them best' (2005: 4).

However, the method preferred by Duran for the revelation of the truth and for the elucidation of alledged misrepresentations was education or 'pedagogy'. The idea of 'pedagogy' appeared throughout the text three times and was given prominence by entitling a whole section 'Pedagogy: the Best Answer to Lack of Information and Falsehood'. In his insistence that the new Statute would not do away with the Spanish single market because, according to him, it is in itself already 'an alleged reality' (2005: 21), he suggested to 'explain the truth to the Spaniards' (2005: 23). In his insistence that, despite accusations, Catalonia has demonstrated economic solidarity with the rest of the Autonomous Communities, Duran enquired, 'don't you believe in the need for pedagogy in order to understand and accept each other better for the sake of a better life together? Well, let us invest our energies in this pedagogy and let us not squander it in propaganda and foolishness' (2005: 24). In reference to Catalonia's 'historical rights' (that is the institutions and laws particular to the region which, according to Duran, do not represent a threat to the integrity of the state) Duran asked:

Can't you, honourable members on both sides of this parliament, really contribute to make public this simple truth, instead of helping to spoil our harmonious life together in the hope of getting political gains out of this catastrophe? (Duran, 2005: 19).

And then he drove home: 'Why not explain the truth? Is it really that hard?' (2005: 19).

It is important to look (albeit briefly) into the implications of the pedagogical set up suggested by Duran. Firstly, by choosing an educational metaphor, Duran's branch of nationalism cancelled out the interpretation of the relationship between Catalonia and the rest of Spain as a doomed and hopeless head-on collision; all it would take, as Duran suggested, was to teach (or 'explain') 'the simple truth'. Secondly, a pedagogical arrangement always implies that the relationship established between Duran's coalition and the rest of the Spanish parties (or even between Catalonia and Spain) is not equal in terms of knowledge. As noted above, in Duran's speech this idea was made explict only in the few moments in which the PP was warned about being mistaken in their perception of Catalonia ('you are wrong'). But, as also noted, in the majority of cases the Spanish political system was depicted not as mistaken but as intentionally misleading, as driven by the harmful intentions of the lies of 'propaganda'. Indeed, in his speech Duran implied that the Spanish political parties do not have anything to learn as they are already aware of the truth that Catalonia has been and intends to continue to be an integral and cooperative part of Spain. It was, therefore, not a question of competence on the part of the Spanish political parties but rather a matter of a willingness to accept and disseminate publicly the 'undisputable truths' with which Duran opened his speech (2005: 2). 
It may be argued that the pedagogical effort advocated by Duran was not addressed to the Members of Parliament but ultimately to the Spanish public (understood here as non-Catalan) which was being kept in a dark world of propaganda, manipulation and lies. In this interpretation, the Spanish constituents were (together with the whole of Catalonia) victims of political mendacity.

Furthermore, Duran conveived of the debate on the Statute as a Grand Moment, or, as he announced at the beginning of his speech: 'ever since the approval of our democratic Constitution this is, in my opinion, the most important debate' (2005: 6). The political significance of the debate rested upon one main feature - it was raised to the category of 'test', it was construed as a possible point of no return in the history of Spain, as a trial that had to be surmounted if the worst were to be prevented.

Let us concentrate first on the apocalyptic element of the speech, whereby Duran created an image of a Spain on the brink of 'catastrophe' (2005: 19) if mendacity triumphed and the new Statute were not to be passed as a law. On the question of the impending disaster allegedly looming over Spain he asked MPs: 'until when, I do insist, can this be sustained? Those who declare their love and defence of Spain, do they really believe their perverse attitude is sustainable?' (2005: 5). In the closing section of his speech Duran warned of the outcome brought about by a possible rejection of the new Statute - if central Parliament 'were to frustrate or sever the reform of the Statute, the consequences would be unforeseeable politically and electorally'13 (2005: 26). And what would these 'unforeseeable consequences' be? Duran spelled them out in the final section of his speech:

'Through falsehood, demagoguery, and confrontation we won't achieve anything but to resurrect the ghosts we thought we had left behind. If we can't manage -all of us- to construct the future by looking at the present and not to the future, what we will make of the present moment is a futile debate and I can't foresee a better future. Can we afford this? I don't think so' (Duran, 2005: 26)

It is worth highlighting from this quote the reference to the "ghosts we had left behind' ${ }^{\prime}$, a euphemistic cliché widely used in Spain to refer to the Civil War, the ultimate epitome of political disintegration and disaster.

Despite the rethoric of chaos and catastrophe used, one can rightly argue, as a device to change political behaviour, the prevailing tone of the speech was sanguine about the possibility of averting total calamity. In line with the ominous language used by Duran, the way suggested in his speech to preclude tragedy was the participation of heroic politicians capable of taking heroic decisions in

\footnotetext{
${ }^{13}$ Here Duran alluded to the other potential catastrophe for Spanish (and Catalan) society: a surge of the more radical brand of Catalan nationalism represented by ERC, if the Statute were rejected or radically transformed in the Spanish Parliament.

${ }^{14}$ 'Ios fantasmas que creíamos superados' in the Spanish original.
} 
moments whose importance is reserved for heroes. For greater dramatic effect Duran reserved his reference to this make-or-break epic moment for his penultimate paragraph:

the greatness of statesmen and stateswomen is not measured by the size of their concessions, but by the moment in which they decide to make them. There are key moments in the history of nations in which courage and audacity are the only convenient form of prudence. If one does not accept the calculated risk of this new era of the history of Spain, Catalonia, and the rest of the peoples of Spain, a great opportunity could be missed (Duran, 2005: 26).

For greater authoritative effect, Duran finished his speech by quoting Jordi Pujol, who in an article in the Barcelona daily La Vanguardia had not only stated that the debate represented a potential landmark in the history of Spain but also insisted on the particular proviso needed to prevent catastrophe: the acceptance of reality. This was the condition that, as this article as shown, was the driving force of Duran's speech: 'It is Spain's greatest hour. Of the whole of Spain. And Catalonia, of course. But above all, without excuses, of the rest of Spain. The moment to reflect and accept reality without prejudice. And the moment for the courage all this requires' (Duran, 2005: 26). 'The reality', needless to say, should be understood as the reality of the CiU version of Catalan nationalism, its particular interpretation of the relationship between Catalonia and the rest of Spain.

\section{THE SPEECH AND ITS HISTORICAL LINKS}

The findings of this article contribute to the understanding of the political narrative patterns employed by the moderate brand of Catalan nationalism represented by $\mathrm{CiU}$ at a very particular juncture in the recent history of Spain. However, the speech should be viewed as a concrete manifestation of a broader narrative with a long history in Catalan politics. Indeed, the double construction of Catalonia as victim of Spain but with a clear 'Spanish' vocation was the line of action taken by La Lliga Regionalista of Prat de la Riba and Cambó (widely regarded as the forefathers of moderate Catalanism ${ }^{15}$ ). In their political manifesto 'For Catalonia and a Greater Spain' (written and published in 1916) they set out to justify the intervention of Catalanists in the affairs of the central Government against the background of a specific historical moment: the First World War. Just as in the analyses provided above, Catalonia was then presented as the 'victim' of Spain, but it was from Catalonia that the redemption of Spain was offered. It constituted what the Spanish historian Javier Tusell called the 'Catalan offer' (Tusell, 1998: 19), a deal that included the Catalan ambition both for the regeneration of Spain and for maximum autonomy within Spain. More recently, the proposals of politi-

\footnotetext{
${ }^{15} \mathrm{Josep}$ Maria Ainaud de Lasarte, who has been a member of the Catalan parliament and Barcelona Councillor for $\mathrm{CiU}$, establishes a clear link between the interventionist and 'modernizing' spirit of La Lliga Catalanista and Catalans in general (Ainaud de Lasarte, J.M. (1996).
} 
cal Catalanism for the whole of the State are based on active intervention in the affairs of Spain. As Jordi Pujol states:

\begin{abstract}
the two main pillars of political Catalanism ... have been, on the one hand ... the national assertion of Catalonia ... But another great pillar of this political Catalanism ... has been the attempt to be effectively present in Spanish politics. With the objective, on the one hand, of giving Spain a structure that allows Catalonia to fit in ... And on the other, to attempt ... a modernization of the State, a degree of modernization of Spain ( $\mathrm{Pi}$ and Pujol, 1996: 224).
\end{abstract}

These were the same points that Duran articulated in his speech.

The idea of sacrifice and the right to be publicly recognized (central to Duran's speech) is also a long-standing claim of the Catalan nationalists. Jordi Pujol himself had already stated in the 1960s that 'we have taken part [in the game of the state] ... with poor results compared to the effort we have made' (Pi and Pujol, 1996: 121); an effort that, at times, has been 'futile' and 'laughed at' (1996: 122). The idea that Catalonia proved its role of donor by making 'all sorts of concessions' during the transition to democracy was noted by Pujol in 1996 (1996: 10).

The choice of the narrative frame of 'heroic test' or 'ordeal' is not new either. In their 1916 Manifesto Prat de la Riba and Cambó insisted that if Spain wished to participate and intervene in the new international order, following the AustroHungarian example, she would have to integrate harmoniously all the nations she is made of, she would have to 'understand the exceptional nature of the moment ... the heroic moment we are passing through' (Tusell, 1998: 177). The context of an international war and a new world order cannot be compared with the domestic political context of the speech analysed here, but the recourse to the strategy of the 'exceptionality of the moment' is tellingly similar. In $1993 \mathrm{CiU}$ justified its pact with PSOE as a step that would provide the necessary political stability needed for preparing for Spain's entry into the European monetary union (which was of utmost importance for Spanish politicians, almost a test of national pride). In 1996 the pact with the PP was explained away under the grand objective of the restructuring of Spain in preparation for the $21^{\text {st }}$ century (with further integration within the EU on the background).

\title{
10. CONCLUSION
}

The specific function of Duran's speech was to persuade Spanish MPs to give their authorisation to start the process of debate of the new Statute. One would have expected the speech to have been based on 'the genus deliberativum', which constitutes 'the model of contributions to parliamentary debate at the end of which immediate decision follows...' (Sauer, 1997: 46). However, Duran's speech had no practical purpose in terms of effect on the final vote since in the Spanish parliament political decisions are taken before the actual parliamentary debate. This fact affected the speech in two interrelated ways: a) there was an almost complete 
absence of the political and economic technicalities involved in the new statute; and $b$ ) the void left by the technicalities was occupied by narrative ${ }^{16}$. The term narrative has not been employed in this article as meaning an 'invented myth', but rather as an ideological articulation of the relationship between Catalonia and the rest of Spain based on a series of 'undisputable truths' that proved that Catalonia is not an enemy of Spain but rather its victim and, at the same time, its self-sacrificial helper. Coherent with this narrative interpretation (long-standing, as seen in section 8), the new Statute was presented as being in accordance with the Spanish Constitution and with the good of Spain as its objective, and not as against Spain.

'Truth' was also the basis for the valorisation of the 'others', in this case the PP and the PSOE as representatives of the Spanish state. Firstly, the Spanish political system was mainly characterized as misleading and manipulative. Secondly, according to Duran, the alledgely mendacious interpretations on the role of Catalonia in Spain (and consequently on the new Statute proposal) carried out by the PP and the PSOE were putting Spain on the verge of a disastrous situation. This potential calamity could be averted, Duran suggested, only if a) the truth were accepted by the Spanish political system; b) if the PP and the PSOE explained it to the rest of Spaniards; and c) if they did not reject or try to excise any parts of the new Statute. These three conditions were established with an ominous threat - either the truth was accepted (and the new Statute proposal approved) or else catastrophe (even war) would set in.

The purpose of this article has not been the assessment of the validity of the claims put forward by Duran in his speech, but it is worth looking (albeit briefly) into why this particular narrative construction should be seen as an ideological production. Let us concentrate on the guiding principle of the speech: truth. It can be argued that Duran was taking 'facts' for 'truths'. For example, it is a fact that CiU entered into a pact with both the PSOE and the PP in the 1990s, but the narrative intepretation of that fact as a 'self-sacrificial' act (what Duran insisted was true) constituted an ideological construction. After all, as a result of the pact with the PSOE the devolution of power to Catalonia was speeded up; and as a condition of the pact with the PP, the Spanish right-wing party would commit itself to further decentralization of the State and to the principle of subsidiarity which involved a further transfer of powers to Catalonia, and a reform of the fiscal system with a new operation based on financial co-responsibility.

It can be rightly argued that this self-sacrificial double construction of CataIonia as victim and helper of a mendacious and pitiless State is an ideological narrative arrangement which serves the economic and political purposes of the brand of Catalanism represented by Duran's coalition Convergència i Unió, which is aware of the dual position of Catalonia in relation to Spain: a region with a strong economy and sense of differentiated political identity, but in turn reliant

\footnotetext{
${ }^{16}$ This fact also explains why Duran could launch an attack on the PP and PSOE at the same time as he was asking for their support.
} 
on the Spanish market and interested in having a say in the Spanish political arena. Furthermore, interpreting the relationship between Catalonia and the rest of Spain using a pedagogical metaphorical frame ${ }^{17}$ is fully consistent with Catalonia's Spanish vocation, as this educational metaphor leaves the door open to mutual understanding, a potentiality that precludes the idea of total separation.

\section{BIBLIOGRAPHY}

AINAUD DE LASARTE, J.M. (1996): Ministros catalanes en Madrid. Barcelona: Planeta.

BARTHES, R. (1987): Image, Music, Text. Glasgow: Fontana Press.

DURAN I LLEIDA, (2005) Intervención del portavoz de CiU en el congreso de los diputados en el debate sobre la propuesta de reforma del Estatut d'autonomía de Catalunya, http://www.ciu.info/media/6489.pdf, consulted on 2//11/05.

GONZÁLEZ ANTÓN, L. (1997): España y las Españas. Madrid: Alianza Editorial.

FISKE, J. (1987): Television Culture: Popular Pleasures and Politics. London: Methuen.

FOX, I. (1997): La Invención de España: Nacionalismo Liberal e Identidad Nacional. Madrid: Cátedra.

JAMESON, F. (1974): The Prison-House of Language: A Critical Account of Structuralism and Russian Formalism. Princeton: Princeton University Press.

LYOTARD, J.F. (1984): The Postmodern Condition: A Report on Knowledge. Manchester: Manchester University Press.

PI, R.; y PUJOL J. (1996): Cataluña, España. Barcelona: Espasa.

PROPP, V. (1984): Morphology of the Folktale. Austin: University of Texas Press.

SAUER, C.: Echoes from Abroad-Speeches for the Domestic Audience: Queen Beatrix' Address to the Israeli Parliament. In SCHÄFFNER C. (ed.) (1997): Analysing Political Speeches. Clevedon: Multilingual Matters.

TUSSELL, J.: Prat de la Riba y "La Nacionalitat Catalana". In PRAT DE LA RIBA, E. (1998): La Nacionalidad Catalana. Madird: Biblioteca Nueva.

TOOLAN, J.M. (1988): Narrative: A Critical Linguistic Introduction. London: Routledge.

'EI PSOE ve 'dudosamente constitucional el Estatut y todos los ministerios harán objeciones', elmundo.es. 4 October 2005 http://www.elmundo.es/papel/2005/10/04/espana/1869787.html

\footnotetext{
${ }^{17}$ The 'pedagogical' relationship between Spain and Catalonia was not at all new to this period. As the Spanish historian Javier Tussell observes, as early as 1916 Prat de la Riba, recommended the Catalanist politician Cambó 'to explain Catalanist ideas in the rest of Spain' (Tussell, 1998: 24); and nowadays it is rather normal for Catalanist politicians to embark on similar 'explanatory' missions in Spain.
} 
96 Revealing the truth: Catalonia. the self-sacrificial victim of Spain

\section{Breve semblanza biográfica del autor:}

Fernando León Solís es profesor de español en University of the West of Scotland. Sus investigaciones académicas se encuentran dentro del campo de los estudios culturales, con un enfoque especial en la construcción de identidades nacionales en los medios de comunicación. Su libro Negotiating Spain and Catalonia: Competing Discourses of National Identity está publicado por Intellect.

(Recibido el 17-02-2010, aceptado el 27-09-2010) 